\title{
Impact of Methyl Jasmonate on Antioxidant Activity and Some Biochemical Aspects of Maize Plant Grown under Water Stress Condition
}

\author{
Z. A. Abdelgawad1, A. A. Khalafaallah', M. M. Abdallah² \\ ${ }^{1}$ Botany Department, Women's College, Ain Shams University, Cairo, Egypt \\ ${ }^{2}$ Biology Department, Agricultural and Biological Division, National Research Centre, Cairo, Egypt \\ Email: maha_eg1908@yahoo.fr
}

Received 24 August 2014; revised 24 September 2014; accepted 6 October 2014

Copyright (C) 2014 by authors and Scientific Research Publishing Inc.

This work is licensed under the Creative Commons Attribution International License (CC BY).

http://creativecommons.org/licenses/by/4.0/

(c) (i) Open Access

\begin{abstract}
A pot-culture study was undertaken to investigate the possible role of Methyl jasmonate (MeJA)treatment on the earlier vegetative growth stage and different chemical constituents of maize cultivar (Giza-2) plants subjected to water stress. The grains were divided into two groups: first group was pre-soaked in water, and the second one was pre-soaked in $50 \mu \mathrm{M}$ MeJA for $8 \mathrm{~h}$. The plants were subjected to different levels of water field capacity (WFC) $65 \%, 55 \%$ and $45 \%$. The results showed that pre-soaking maize grains with MeJA led to increases in plant growth criteria evident in terms of plant height, fresh and dry weight of plant. The pigment levels concomitantly with total carbohydrates, total soluble sugar, polysaccharides, as well as free amino acids, proline and total protein content were markedly increased. Moreover, the application of the investigated MeJA significantly improved growth hormone in terms of IAA. In contrast ABA level was markedly declined in maize plant. The activities of oxidative CAT, POX and SOD were also increased with MeJA. In addition, the $N, P$ and $K$ content was increased significantly in shoot. As a conclusion, soaking maize grains with MeJA could alleviate the harmful effects of water stress.
\end{abstract}

\section{Keywords}

Methyl Jasmonate, Maize, Growth, Chlorophyll, Water Stress, IAA, ABA, Oxidative Enzymes

\section{Introduction}

Maize is an important staple C4 food crop in many countries of the world and it accounts for around 712 million

How to cite this paper: Abdelgawad, Z.A., Khalafaallah, A.A. and Abdallah, M.M. (2014) Impact of Methyl Jasmonate on Antioxidant Activity and Some Biochemical Aspects of Maize Plant Grown under Water Stress Condition. Agricultural Sciences, 5, 1077-1088. http://dx.doi.org/10.4236/as.2014.512117 
metric tons in 2006. Corn is very susceptible to drought damage due to the plant's requirement for water for cell elongation and its inability to delay vegetative growth. The amount of yield loss that occurs during dry weather depends on what growth stage the corn is in and how severe the dry conditions become [1].

Drought is one of the most serious world-wide problems for agriculture. It refers to the absence of adequate moisture required for a plant to grow normally and complete its life cycle [2]. Four-tenths of the world's agricultural land lies in arid or semi-arid regions. Water stress is one of the most important environmental stresses that can regulate plant growth and development, limit plant production, and alter the physiological and biochemical properties of plants. Plants can respond and adapt water stress by altering their cellular metabolism to invoke various defence mechanisms [3] and [4]. It involves the synthesis and accumulation of small compatible solutes (osmolytes), such as proline, glycine betaine, sugars and some inorganic ions [5]. These compounds help the cells to maintain their dehydrated state and the structural integrity of the membranes so as to provide resistance against drought and cellular dehydration [6]. In addition, drought stress often leads to the accumulation of reactive oxygen species (ROS). Excessive ROS production can cause oxidative stress to the photosynthetic apparatus seriously impair the normal function of cells [7].

Phytohormones are part of signaling pathways or their presence may stimulate signaling reactions or molecules that are responsible for plants to response stresses. A class of phytohormones, jasmonates derived from the metabolism of membrane fatty acids, attracted considerable attention [8]. Methyl jasmonate (MeJA) is a naturally occurring plant growth regulator which can affect many morphological, physiological and biochemical processes in plants [9] [10]. MeJA is generally considered to inhibit stomatal opening, cell division, plant growth and photosynthetic activities [11]. Foliar application of MeJA modulates several physiological responses, leading to improved resistance against abiotic stresses [12]. However, the role of MeJA in protecting plants from various abiotic stresses has been controversial. For instance, MeJA was reported to improve resistance against drought in rice [13]. Exogenously applied, jasmonates elicit several different physiological responses to stress and therefore increase plant resistance [12] [14]. The octadecanoic pathway represents the series of metabolic steps through which jasmonates are synthesized following oxidation of linolenic acid [15]. Phyto-hormones are in a prominent position, playing important regulatory roles in plant physiology [16] [17]. The alleviation of oxidative damage and increase resistance to environmental stresses, at critical growth stages of plant, are often correlated with an efficient antioxidative system.

The present work aimed to determine the role of Methyl jasmonate (MeJA) in increasing maize plants resistance to water stress.

\section{Materials and Methods}

\subsection{Plant Materials, Growth and Treatment Conditions}

Grains of maize (Zea maize L.) cv. Giza-2 were obtained from Agriculture Research Centre, Ministry of Agriculture, Giza, Egypt. Grains were grown in pots (diameter $35 \mathrm{~cm}$ and $40 \mathrm{~cm}$ depth); each pot contained $7 \mathrm{~kg}$ soil. Soil characteristics were: sandy loam in texture, sand $84.2 \%$, silt $12.9 \%$, clay $2.9 \%$, $\mathrm{pH} 7.7$, EC $0.5 \mathrm{dSm}^{-1}$ and organic matter $1.2 \%$. Irrigation treatments were given to plants for different levels of water field capacity $65 \%$, $55 \%$ and $45 \%$. The grains were divided into two groups, the first group were pre-soaked in distilled water (control), and the second group were pre soaked in $50 \mu \mathrm{M}$ MeJA for $8 \mathrm{~h}$ for each. Seven grains were sown per pot and were thinned to four after two weeks from planting. Five replicates were used per each treatment.

\subsection{The Experimental Design}

\section{Control and Irrigation Intervals}

Irrigation every two days, soil moisture content depleted from $100 \%$ to $65 \%$ of field capacity.

Irrigation every four days, soil moisture content depleted from $100 \%$ to $55 \%$ of field capacity.

Irrigation every six days, soil moisture content depleted from $100 \%$ to $45 \%$ of field capacity.

\section{Methyle jasmonat treatments:}

Grains were presoaked in $50 \mu \mathrm{M}$ MeJA for $8 \mathrm{~h}$ and after sowing irrigated every two days, soil moisture content depleted from $100 \%$ to $65 \%$ of field capacity.

Grains were presoaked in $50 \mu \mathrm{M}$ MeJA for $8 \mathrm{~h}$ and after sowing irrigated every four days, soil moisture content depleted from $100 \%$ to $55 \%$ of field capacity.

Grains were presoaked in $50 \mu \mathrm{M}$ MeJA for $8 \mathrm{~h}$ and after sowing irrigated every six days, soil moisture content 
depleted from $100 \%$ to $45 \%$ of field capacity. The fertilization with super phosphate ( $5 \mathrm{~g} / \mathrm{pot})$, potassium sulfate (2.5 g/pot) and urea (6 g/pot) were used. Plants were harvested at 35 days from sowing to take the morphological measurements and determine different biochemical components.

\section{Growth analysis}

Samples were taken after 35 days (vegetative stage) from sowing to determine vegetative growth in terms of morphological parameters, endogenous phytohormones (auxins and abscisic acid), photosynthetic pigment (chlorophyll a, chlorophyll b and carotenoids), carbohydrate fractions (total soluble sugars, polysaccharides and total carbohydrates), nitrogen components (proline, total free amino acid, protein), activity of antioxidant enzymes (CAT and SOD) and the element composition (Potassium, Sodium and Phosphorus) were determined.

\subsection{Photosynthetic Pigments Content}

Total chlorophyll a and b and carotenoids contents in fresh leaves were determined using the method of [18]. The fresh tissue was ground in a mortar and pestle using $80 \%$ acetone filtrated through Whatman No. 1 . The optical density (OD) of the solution was recorded at 662 and $645 \mathrm{~nm}$ (for chlorophyll a and b) and $470 \mathrm{~nm}$ for carotenoids, respectively using a spectrophotometer (Shimadzu UV-1700, Tokyo, Japan). Values of photosynthetic pigments were expressed in mg/100g FW.

\subsection{Total Soluble Sugars (TSS) Content}

Total soluble sugers (TSS) were extracted by overnight submersion of dry tissue in $10 \mathrm{ml}$ of $80 \%(\mathrm{v} / \mathrm{v})$ ethanol at $25^{\circ} \mathrm{C}$ with periodic shaking, and centrifuged at $600 \mathrm{rpm}$. The supernatant was evaporated till completely dried then dissolved in a known volume of distilled water to be ready for determination of soluble carbohydrates [19]. TSS were analyzed by reacting of $0.1 \mathrm{ml}$ of ethanolic extract with $3.0 \mathrm{ml}$ freshly prepared anthrone (150 mg anthrone $+100 \mathrm{ml} 72 \% \mathrm{H}_{2} \mathrm{SO}_{4}$ ) in boiling water bath for ten minutes and reading the cooled samples at $625 \mathrm{~nm}$ using Spekol Spectrocolorimeter VEB Carl Zeiss [20].

\subsection{Total Carbohydrates Content}

Determination of total carbohydrates was carried out according to [21]. 0.2 - $0.5 \mathrm{~g}$ of dried of maize (Zea maize L.) cv. tissue was placed in a test tube, and then $10 \mathrm{ml}$ of sulphuric acid $(1 \mathrm{~N})$ was added. The tube was sealed and placed overnight in an oven at $100^{\circ} \mathrm{C}$. The solution was then filtered into a measuring flask $(100 \mathrm{ml})$ and completed to the mark with distilled water. The total carbohydrates were determined colorimeterically according to the method of [22] as follows: An aliquot of $1 \mathrm{ml}$ of this solution was transferred into test tube and treated with $1 \mathrm{ml}$ of $5 \%$ aqueous phenol solution followed by $5 \mathrm{ml}$ of concentrated sulphuric acid. The tubes were thoroughly shaken for ten minutes then placed in a water bath at $23^{\circ} \mathrm{C}-30^{\circ} \mathrm{C}$ for 20 minutes. The optical density of the developed color was measured at $490 \mathrm{~nm}$ using Shimadzu spectrophotometer model UV 1201.

\subsection{Proline Content}

Proline was assayed according to the method described by [23]. $2 \mathrm{ml}$ of maize tissue extract, $2 \mathrm{ml}$ of acid ninhydrin and $2 \mathrm{ml}$ of glacial acetic acid were added and incubated for $1 \mathrm{~h}$ in a boiling water bath followed by an ice bath. The absorbance was measured at $520 \mathrm{~nm}$ using Spekol Spectrocolourimeter VEB Carl Zeiss. A standard curve was obtained using known concentration of authentic proline, following the same procedure.

\subsection{Free Amino Acids Content}

Free amino acid content was extracted according to the method described by [24]. Free amino acid was determined with the ninhydrin reagent method [25]. One ml acetate buffer (pH 5.4) and $1 \mathrm{ml}$ chromogenic agent were added to $1 \mathrm{ml}$ free amino acid maize tissue extract. The mixture was heated in boiling water bath for $15 \mathrm{~min}$ after cooled in tap water, $3 \mathrm{ml}$ ethanol $(60 \% \mathrm{v} / \mathrm{v})$ was added. The absorbance at $570 \mathrm{~nm}$ was then monitored using Spekol Spectrocolourimeter VEB Carl Zeiss.

\subsection{Total Protein Content}

Total protein concentration of the supernatant was determined according to the method described by [26] with 
bovine serum albumin as a standard. An amount of 2 gm of samples were grinded in mortar with $5 \mathrm{ml}$ of phosphate buffer ( $\mathrm{pH} 7.6)$ and was then transformed to the centrifuge tubes. The homogenate was centrifuged at $8000 \mathrm{rpm}$ for 20 minutes. The supernatant of different samples of maize tissue extract were put in separate tubes. The volume of all of the samples in tubes were then made equal by adding phosphate buffer solution and the extraction were stored in the refrigerator at $40^{\circ} \mathrm{C}$ for further analysis. After extraction, $30 \mu \mathrm{l}$ of different samples were taken out in separate tubes and were mixed with $70 \mu \mathrm{l}$ of distilled water separately. In all of these separate sample tubes $2.9 \mathrm{ml}$ of Coosmassic Brillaint Blue solution was then added and mixed thoroughly. The Total volume now was $3 \mathrm{ml}$ in each tube. All these tubes were incubated for 5 minutes at room temperature and absorbance at $600 \mathrm{~nm}$ was recorded against the reagent blank. A standard curve of Absorbance (600 nm) versus Concentration $(\mu \mathrm{g})$ of protein was calculated.

\subsection{Endogenous Phytohormones (Auxins and Abscisic Acid) Content}

Extraction, separation and determination of phytohormones (auxins and abscisic acid) were essentially similar to that adopted by [27] and the Methylation of fresh maize tissue was carried out according to the method described [27]. Identification and determination of auxins, and abscisic acid were carried out by gas liquid chromatography (5890) with a flame ionization detector [28].

\subsection{Assay of Enzymes Activities Content}

Enzyme extractions were collected following the method described by [29]. Leaf tissues were homogenized in ice-cold phosphate buffer (50 mM, pH 7.8), followed by centrifugation at 8,000 rpm and $4^{\circ} \mathrm{C}$ for $15 \mathrm{~min}$. The supernatant was used immediately to determine the activities of the following enzymes.

1). Peroxidase (POX, EC 1.11.1.7)

Its activity was assayed by the method of [30]. The reaction mixture used for estimating the peroxidase enzyme (POX) contained $2 \mathrm{ml}$ of $0.1 \mathrm{M}$ phosphate buffer (pH 6.8), $1 \mathrm{ml}$ of $0.01 \mathrm{M}$ pyrogallol, $1 \mathrm{ml}$ of $0.005 \mathrm{M}$ $\mathrm{H}_{2} \mathrm{O}_{2}$ and $0.5 \mathrm{ml}$ of the enzyme extract. The solution was incubated for $5 \mathrm{~min}$ at $25^{\circ} \mathrm{C}$ after which the reaction was terminated by adding $1 \mathrm{ml}$ of $2.5 \mathrm{~N} \mathrm{H}_{2} \mathrm{SO}_{4}$. The amount of purpurogallin formed was determined by measuring the absorbance at $420 \mathrm{~nm}$ against a reagent blank prepared by adding the extract after the addition of 2.5 $\mathrm{N} \mathrm{H}_{2} \mathrm{SO}_{4}$ at the zero time.

2). Superoxide Dismutase (SOD; EC 1.15.1.1)

SOD activity was measured according to [31].

3). Catalase (CAT, EC 1.11.1.6)

Its activity was determined spectrophotometrically by following the decrease in absorbance at $240 \mathrm{~nm}$ [29]. The mixture ( $3 \mathrm{ml}$ ) contained $1.9 \mathrm{ml}$ phosphate buffer ( $50 \mathrm{mM}, \mathrm{pH} 7.0), 100 \mu \mathrm{l}$ enzyme extract, and $1 \mathrm{ml} 0.3 \%$ $\mathrm{H}_{2} \mathrm{O}_{2}$. The reaction was initiated by adding enzyme extract. One unit of CAT activity was defined as the 0.01 deduction in absorbance at $240 \mathrm{~nm}$ per minute.

\subsection{Mineral Contents}

$\mathrm{N}$ and P were determined using Spekol Spectrocolourimeter VEB Carl Zeiss. While, K content was estimated by flame photometer according to the method described by [32].

Statistical analysis: the obtained data were treated statistically using the one-way analysis of variance as described by [33]. Means were compared by LSD at 5\% using Spss program version 16.

\section{Results and Discussion}

\subsection{Vegetative Growth}

Table 1 shows the effect of MeJA on growth criteria of maize plants at different levels of soil drought stress. Plants grown under $55 \%$ or $45 \%$ of water field capacity led to marked decreases in all morphological parameters studied (plant height, fresh and dry weight of shoots) when compared to plants grown under the level of $65 \%$ of water holding capacity. Pre-soaking of maize grains with $50 \mu \mathrm{M}$ MeJA increased all growth criteria under different water levels. The maximum increases in all growth criteria were obtained by using $65 \%$ water field capacity. Drought, being the most important environmental stress, severely hampers plant growth and develop- 
Table 1. Effect of Methyl jasmonate (MeJA) on growth criteria and chlorophyll content of maize plant subjected to different levels of water field capacity.

\begin{tabular}{|c|c|c|c|c|c|c|c|}
\hline \multicolumn{2}{|c|}{ Treatment } & \multirow{2}{*}{$\begin{array}{l}\text { Shoot length } \\
\text { (cm) }\end{array}$} & \multirow{2}{*}{$\begin{array}{c}\text { Fresh weight } \\
\text { of shoot (g) } \\
\text { - }\end{array}$} & \multirow{2}{*}{$\begin{array}{l}\text { Dry weight of } \\
\text { shoot (g) } \\
\text { - }\end{array}$} & \multirow{2}{*}{$\begin{array}{l}\text { Chlorophyll a } \\
\text { (mg/g fresh } \\
\text { weight) } \\
\text { - }\end{array}$} & \multirow{2}{*}{$\begin{array}{l}\text { Chlorophyll b } \\
\text { (mg/g fresh } \\
\text { weight) } \\
\text { - }\end{array}$} & \multirow{2}{*}{$\begin{array}{c}\text { Carotinoids } \\
\text { (mg/g fresh } \\
\text { weight) } \\
\text { - }\end{array}$} \\
\hline & WFC & & & & & & \\
\hline & $65 \%$ & $52.8 b$ & $240 b$ & $26.2 b$ & $3.9 \mathrm{~b}$ & $1.83 a$ & $0.95 b$ \\
\hline & $55 \%$ & $46.2 \mathrm{c}$ & $200.3 c$ & $23.5 b c$ & $3.3 c$ & $1.61 \mathrm{~b}$ & $0.71 \mathrm{c}$ \\
\hline & $45 \%$ & 35.3e & $140.0 \mathrm{e}$ & $16.3 \mathrm{~d}$ & $2.1 d$ & $1.13 \mathrm{~d}$ & $0.45 d$ \\
\hline \multirow{3}{*}{$\begin{array}{l}50 \mu \mathrm{M} \\
\text { MeJA }\end{array}$} & $65 \%$ & $58.5 \mathrm{a}$ & $275.2 \mathrm{a}$ & $30.3 a$ & $4.8 \mathrm{a}$ & $1.95 \mathrm{a}$ & $1.62 \mathrm{a}$ \\
\hline & $55 \%$ & $50.3 b$ & $228.0 \mathrm{~b}$ & $24.7 b$ & $3.9 \mathrm{~b}$ & 1.76ab & $1.45 \mathrm{a}$ \\
\hline & $45 \%$ & $40.5 d$ & 185.6d & $21.2 \mathrm{c}$ & $3.6 \mathrm{bc}$ & $1.38 \mathrm{c}$ & $1.01 \mathrm{~b}$ \\
\hline
\end{tabular}

ment, limits plant production and the performance of crop plants, more than any other environmental factor. It is now becoming evident that, methyl jasmonate can act as a true plant hormone, which mediates in various aspects of development and stress responses. [11] and [34] stated that the application of MeJA to a plant evokes a wide variety of morphological, physiological and biochemical responses to stress. Growth is one of the most drought sensitive processes due to the reduction in turgor pressure [35]. [11] mentioned that water deficit substantially reduced the plant height, the lowest node height, leaf area, stem diameter, number of nodes and branches plausibly by decreasing the soil's water potential in soybean plant.

\subsection{Photosynthetic Pigments Contents}

Data in (Table 1) show the response of photosynthetic pigment of maize leaves, grains pre-soaked with MeJA and subjected to different levels of WFC in soils. The level 65\% of WFC led to considerable increases in chlorophyll a, chlorophyll b and carotenoids contents while decrease of the WFC to $45 \%$ led to decreases in all photosynthetic fractions as compared to $65 \%$. The results showed that plants treated with MeJA led to increases in photosynthetic pigments at all levels of drought stress when compared to the corresponding control plants. Drought stress might reduce leaf net photosynthetic assimilation by both stomatal and metabolic limitations [36]. In addition, many studies were reported that stomatal effects were major under moderate stresses, but biochemical limitations are quantitatively important during leaf ageing or during severe drought [37]. Increasing drought stress causes a reduction in chlorophyll contents (Table 1). These results could be in harmony with those obtained by [38] who suggested that the source of reducing energy for ROS scavenging during stress accompanied by suppression of photosynthetic apparatus. In addition, [39] attributed the reduction in chlorophyll content to the suppression of specific enzymes that are responsible for the synthesis of photosynthetic pigments. The reduction in chlorophyll contents in response to drought stress was mainly due to the stomatal closure due to ABA increase in cowpea plants [40].

\subsection{Total Soluble Sugar, Polysaccharides and Total Carbohydrate}

The effect of MeJA on the total soluble sugar (TSS), polysaccharides and total carbohydrates of maize plant under drought stress are shown in Figure 1. Data demonstrate that up to 55\% field capacity led to marked increase in total soluble sugars compared to plants grown under $65 \%$ of field capacity. On the other hand, MeJA treatment caused significant increases in total soluble sugar, polysaccharides and total carbohydrate at the level 65, 55 and $45 \%$ of WFC, as compared with the corresponding untreated plants. MeJA treatment combined with 55\% of SWHC was the most effective treatment as compared with the corresponding control. The data herein revealed that pre-soaking grains with MeJA stimulated the accumulation of total soluble sugars, polysaccharides and total carbohydrate. The increase in sugar concentration may be a result from the degradation of starch, [41]. Starch may play an important role in accumulation of soluble sugars in cells. Starch depletion may occur in response to drought stress [42]. The concentrations of soluble sugars increased at the same time as a decrease in the starch concentration was observed by [15]. The tolerance mechanism in water deficit may be associated with accumulation of osmoprotectants such as soluble sugars. The accumulation of soluble sugars is strongly correlated to the acquisition of drought tolerance in plants [43]. 


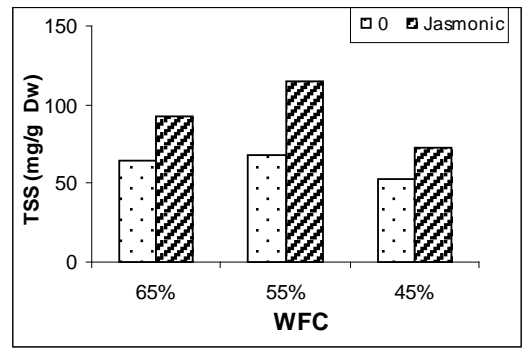

LSD at 5\%: 10.4

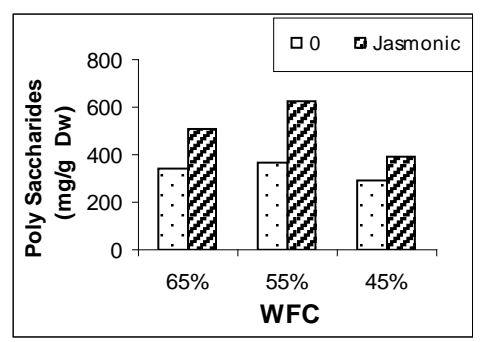

LSD at 5\%: 42.6

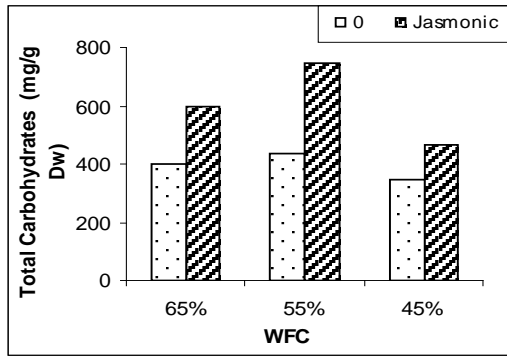

LSD at 5\%: 35.8

Figure 1. Effect of Methyl jasmonate (MeJA) on TSS, Polysaccharides and total carbohydrates contents (as mg/g dry wt) of maize plant subjected to different levels of water field capacity.

\subsection{Proline, Free Amino Acids and Protein Contents}

Data illustrated in Figure 2 shows that MeJA increased proline, free amino acids content and total protein compared to the corresponding untreated plant. Data also revealed that decrease WFC led to marked increases of free amino acids contents compared to plants grown under $65 \%$ of WFC. In the main time, decrease of WFC down to $45 \%$ led to marked increase in proline content compared to plants grown under $55 \%$ or $65 \%$ of WFC. On the other hand, total protein content considerably increase with decreasing in the WFC. The exposure of maize plant to drought stress induced an accumulation of free amino acids and degradation of total protein (Figure 2). These results are in agreement with those reported by [44] [45]. These results can be attributed to the decrease in protein synthesis and/or to the increase in its degradation. Many functions have been postulated for proline accumulation in plant tissues, proline and free amino acids could be involved in the osmotic adjustment of plants [46]. and could also be a protective agent of enzymes and membranes [47]. Amino acid accumulation occurs not only under salinity but also under drought stress in higher plants [48]. Increased levels of specific amino acids had a beneficial effect during stress acclimation [49]. When plant subjected to drought stress plants maintain their water content by accumulation of compatible organic solutes act as osmoprotectants, such as proline, in their cytoplasm [50]. Proline also functions as hydroxyl radical scavenger [51]. [52] showed that the proline content was higher in drought stressed shoot tips and it was the highest in the stressed shoot tips supplemented with MeJA. Similarly, [11] asserted that MeJA application further enhanced the proline contents and also helped to maintain relative water content in drought stressed soybean plants as compared with the respective controls. Crop plants react to water deficiency leading to tolerance against drought stress by changing some physiological and biochemical attributes [53], therefore, treatment of banana shoot tips with MeJA caused an increase in proline accumulation as a physiological change which might be associated with the strategies which match the plant in order to withstand drought stress conditions.

\subsection{Indole Acetic Acid (IAA) and Absisic Acid Content}

Data in Figure 3 show the variation in IAA in response to Pre-soaking plant with MeJA. The WFC of 45\% caused marked decreases in IAA and increased ABA content as compared with those of the corresponding controls, while WFC up to 65\% led to significant increases in IAA and decreased ABA content. There is slight increase in IAA combined with reduction in inhibitor ABA in response to MeJA. Pre-soaking grains with MeJA 


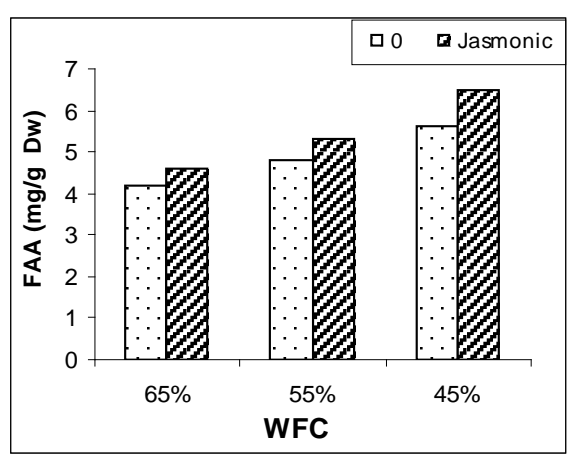

LSD at 5\%: 0.42

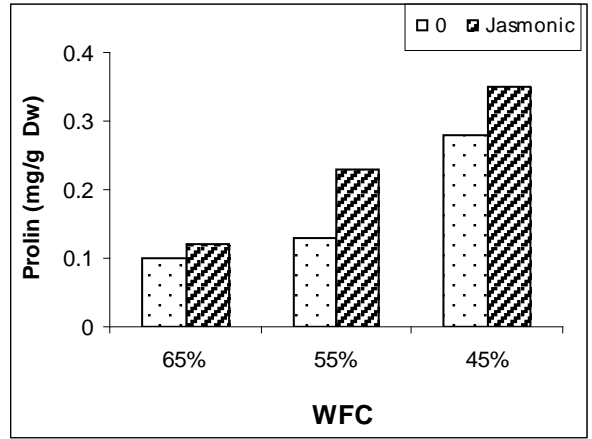

LSD at 5\%: 0.06

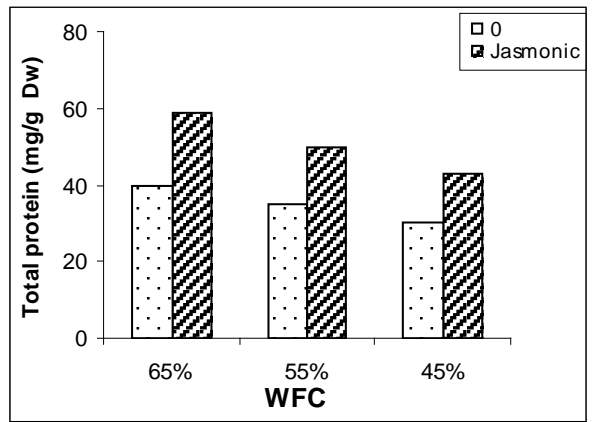

LSD at 5\%: 4.2

Figure 2. Effect of Methyl jasmonate (MeJA) on proline, free amino acid and protein contents (as mg/g dry wt) of maize plant subjected to different levels of water field capacity.

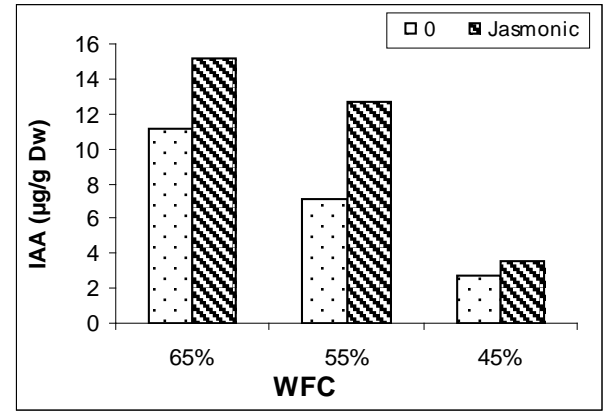

LSD at 5\%: 0.426

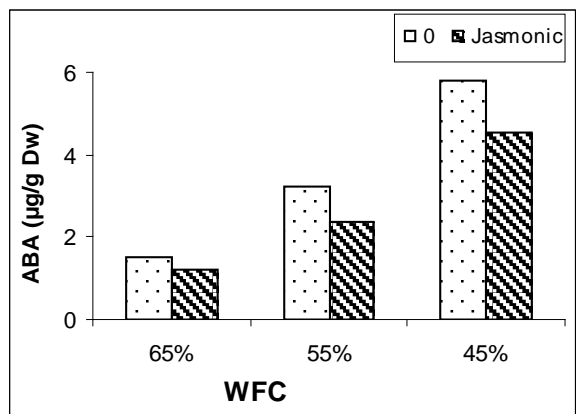

LSD at 5\%: 2.12

Figure 3. Effect of Methyl Jasmonate (MeJA) on ABA and IAA contents (as mg/g dry wt) of maize plant subjected to different levels of water field capacity.

increased growth promoters accompanied with reduction in ABA as compared with control plant. It could be concluded that this increase might be due to the role of endogenous hormone in stimulating cell division and/or the cell enlargement and this in turn improved plant growth. In this connection, [54] reported that MeJA promoted plant growth via increase in IAA and cytokinins under no stress conditions. Moreover, [55] found that the JA treatment caused accumulation of both ABA and IAA in wheat seedlings.Drought stress increases abscisic acid (ABA) levels in maize reproductive tissue, and the change was correlated with a decreased kernel set [56]. An increase in abscisic acid (ABA) content was due to osmotic stress which played a central role in the plant response to drought [57].

\subsection{Enzyme Activities}

The changes in the activities of the various enzymes in response to drought stress and MeJA are illustrated in 
(Figure 4). Results indicated that, catalase (CAT), super oxide desmiotase (SOD) and peroxidase (POX) were slightly increased under stress conditions. Pre-soaking plants with MeJA improved stress resistance by the increase in CAT, SOD and POX activities as compared with corresponding drought stress level. These results are in agreement with [58] who found that MeJA (50 and $100 \mu \mathrm{M})$ promoted increased production of several antioxidative enzymes. It seems that MeJA plays a role in single transduction pathway in oxidative stress by the increase in CAT, SOD and POX activity. [59] reported also that signal transduction by MeJA occurs around 50 $\mu \mathrm{mol}$ and becomes inhibitory at concentration above $100 \mu \mathrm{mol}$. It has been reported that MeJA mitigated the ROS effects in straw berry under drought stress and in maize seedlings subjected to paraquat [58]. In strawberry leaves, it shown that MeJA changed the ratio of membranes fatty acids, which was less, targeted for free radicals [60]. In order to repair the damage initiated by ROS, plants evolve complex antioxidant metabolism. This includes enzymes like SOD, CAT, APX, GPX and nonenzymes like ascorbate and glutathione [61]. There is information that shows MeJA affects on the activity and/or pools of stress enzymes and causes the alleviation of oxidative stress [62] [63]. [64] reported that the activities of CAT, POX and SOD were increased in the leaves on account of MeJA treatment. They also mentioned that the application of MeJA further enhanced the activities of all antioxidant enzymes, both in nonstressed and stressed plants, by supplementing the ROS scavenging mechanism. MeJA could induce antioxidant defense activity in plants to remove the possible toxic effects of free radicals, making the plants more resistant. Mitigation of ROS effects by MeJA was reported in the case of strawberry under drought stress and in maize seedlings subjected to paraquat [59].

\subsection{Mineral Contents}

Figure 5 shows that WFC at 65\% led to slight increase in both potassium and phosphorus, while $45 \%$ WFC led to a marked decrease in potassium content compared to corresponding plant control. $45 \%$ WFC caused marked

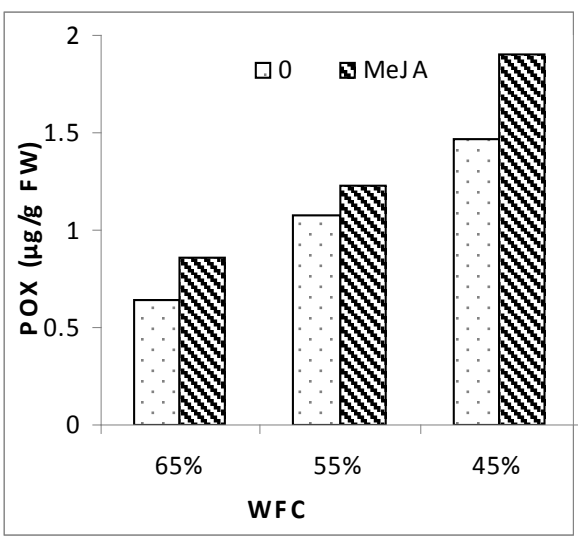

LSD at 5\%: 0.21

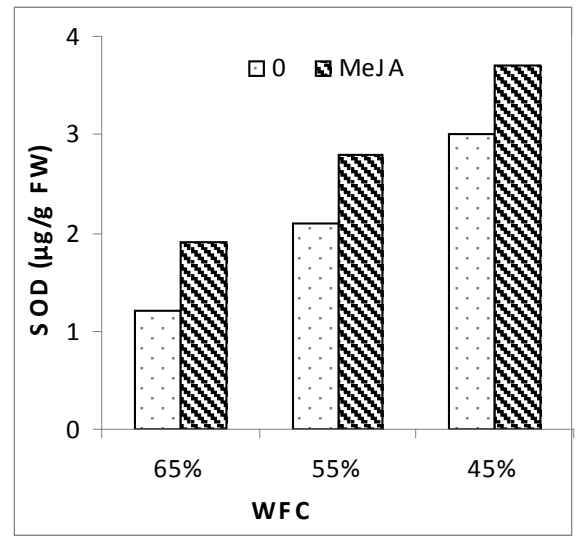

LSD at 5\%: 0.58

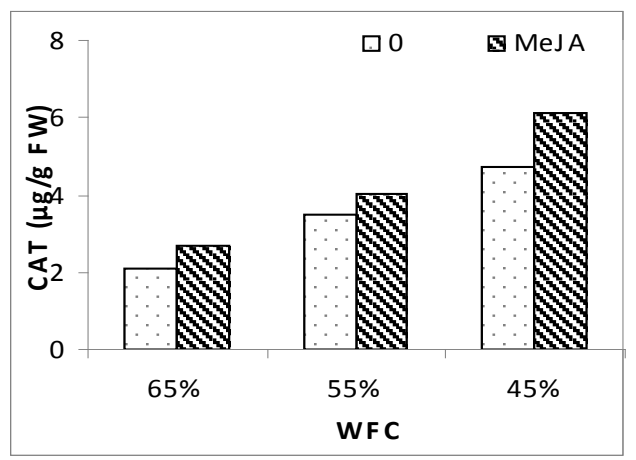

LSD at 5\%: 0.87

Figure 4. Effect of Methyl jasmonate (MeJA) on enzymatic activity (as $\mu \mathrm{g} / \mathrm{g} F W$ ) of maize plant subjected to different levels of water field capacity. 


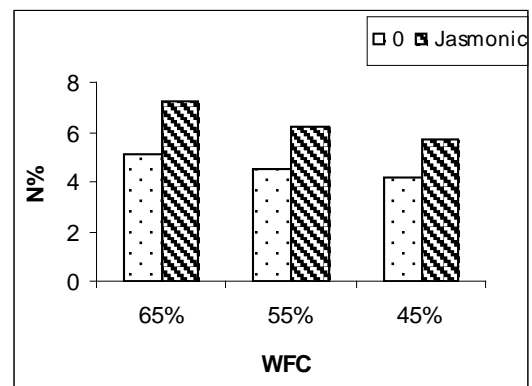

LSD at 5\%: 0.52

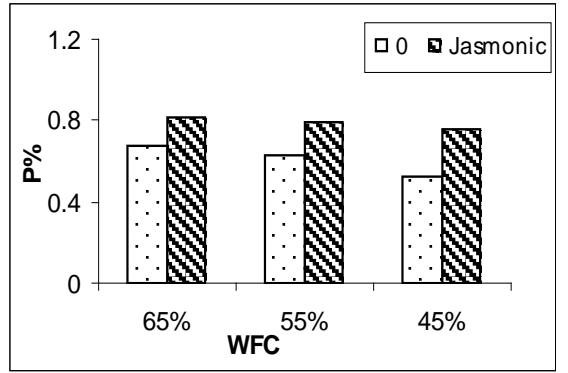

LSD at 5\%: 0.75

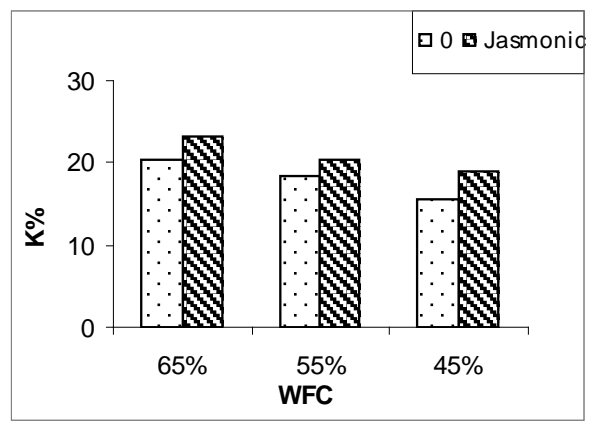

LSD at 5\%: 2.2

Figure 5. Effect of Methyl jasmonate (MeJA) on mineral contents Nitrogen (N), Phosphorus (P) and Potassium (K) as percent of maize plant subjected to different levels of water field capacity (WFC).

increases in nitrogen percent as compared with the corresponding controls. Drought stress caused considerable decreases in nitrogen at treatment 65\% WFC of soil levels (Figure 5) as compared with the corresponding control. The results showed that pre-soaking plant with MeJA led to increase in potassium, phosphorus, and nitrogen, either in normal conditions or under different drought stress treatments. Potassium plays a key role in plant metabolism. It activates a range of enzymes, and plays a key role in plant drought stress and has been found to be the cationic solute which is responsible for stomatal movement in response to changes in bulk leaf water status [65] [66].

In addition, [67] observed that mild and severe drought stress reduced the uptake of NPK in wheat plants compared to that of normal conditions. These results are in accordance with those obtained by [68] in wheat plants. Also [69] indicate that drought stress treatments affected on both NPK percentages and uptakes in stress tissues negatively compared to untreated plants.

\section{Conclusion}

In conclusion, Methyl jasmonate improves maize growth growing under drought stress by inducing plants to increase organic osmoprotectants (proline, total soluble sugars and free amino acids), certain growth hormone and oxidative enzymes activity (peroxidase, superoxide dismutase and catalse).

\section{References}

[1] Heinigre, R.W. (2000) Irrigation and drought management. Crop Science Department. http://www.ces.ncsu.edu/plymouth/cropsci/cornguide/Chapter4.html

[2] Zhu, J.K. (2002) Salt and Drought Stress Signal Transduction in Plants. Annual Review of Plant Biology, 53, $247-258$. http://dx.doi.org/10.1146/annurev.arplant.53.091401.143329

[3] Gulen, H. and Eris, A. (2004) Effect of Heat Stress on Peroxidase Activity And total Protein Content in Strawberry Plants. Plant Science, 166, 739-744. http://dx.doi.org/10.1016/j.plantsci.2003.11.014

[4] El-Tayeb, M.A. (2006) Differential Response of Two Vicia faba Cultivars to Drought: Growth, Pigments, Lipid Peroxidation, Organic Solutes, Catalase and Peroxidase Activity. Acta Agronomica Hungarica, 54, 25-37. http://dx.doi.org/10.1556/AAgr.54.2006.1.3 
[5] Chaves, M.M., Maroco, J.P. and Pereira, J.S. (2003) Understanding Plant Responses to Drought from Genes to the Whole Plant. Functional Plant Biology, 30, 239-264. http://dx.doi.org/10.1071/FP02076

[6] Ramanjulu, S. and Bartels, D. (2002) Drought and Desiccation-Induced Modulation of Gene Expression in Plants. Plant, Cell and Environment, 25, 141-151. http://dx.doi.org/10.1046/j.0016-8025.2001.00764.X

[7] Niyogi, K.K. (1999) Photoprotection Revisited: Genetic and Molecular Approaches. Annual Review of Plant Physiology and Plant Molecular Biology, 50, 333-359. http://dx.doi.org/10.1146/annurev.arplant.50.1.333

[8] Avanci, N.C., Luche, D.D., Goldman, G.H. and Goldman, M.H.S. (2010) Jasmonates Are Phytohormones with Multiple Functions, Including Plant Defense and Reproduction. Genetics and Molecular Research, 9, 484-505.

[9] Ueda, J. and Saniewski, J. (2006) Methyl Jasmonate-Induced Stimulation of Chlorophyll Formation in the Basal Part of Tulip Bulbs Kept under Natural Light Conditions. Journal of Fruit and Ornamental Plant Research, 14, 199-210.

[10] Norastehnia, A., Sajedi, R.H. and Nojavan-Asghari, M. (2007) Inhibitory Effects of Methyl Jasmonate on Seed Germination in Maize (Zea Mays L.): Effect on Amylase Activity and Ethylene Production. General and Applied Plant Physiology, 33, 13-23.

[11] Anjum, S.A., Wang, L.C., Farooq, M., Hussain, M., Xue, L.L. and Zou, C.M. (2011) Brassinolide Application Improves the Drought Tolerance in Maize through Modulation of Enzymatic Antioxidants and Leaf Gas Exchange. Journal of Agronomy and Crop Science, 197, 177-185. http://dx.doi.org/10.1111/j.1439-037X.2010.00459.X

[12] Walia, H., Wilson, C., Condamine, P., Liu, X., Ismail, A.M. and Close, T.J. (2007) Large-Scale Expression Profiling and Physiological Characterization of Jasmonic Acid-Mediated Adaptation of Barley to Salinity Stress. Plant, Cell \& Environment, 30, 410-421. http://dx.doi.org/10.1111/j.1365-3040.2006.01628.x

[13] Lee, T.M., Lur, H.S., Lin, V.H. and Chu, C. (1996) Physiological and Biochemical Changes Related to Methyl Jasmonate-Induced Chilling Tolerance of Rice (Oryza sativa L.) Seedlings. Plant, Cell \& Environment, 19, 65-74. http://dx.doi.org/10.1111/j.1365-3040.1996.tb00227.x

[14] Ding, C.K., Wang, C.Y., Gross, K.C. and Smith, D.L. (2002) Jasmonate and Salicylate Induce the Expression of Pathogenesis-Related-Proteins Genes and Increase Resistance to Chilling Injury in Tomato Fruit. Planta, 214, 895-901. http://dx.doi.org/10.1007/s00425-001-0698-9

[15] Ketabchi, S. and Shahrtash, M. (2011) Effects of Methyl Jasmonate and Cytokinin on Biochemical Responses of Maize Seedlings Infected by Fusarium moniliforme. Asian Journal of Experimental Biological Sciences, 2, 299-305.

[16] Chen, H., Jones, A.D. and Howe, G.A. (2006) Constitutive Activation of the Jasmonate Signaling Pathway Enhances the Production of Secondary Metabolites in Tomato. FEBS Letters, 580, 2540-2546. http://dx.doi.org/10.1016/j.febslet.2006.03.070

[17] Browse, J. (2009) Jasmonate Passes Muster: A Receptor and Targets for the Defense Hormone. Annual Review of Plant Biology, 60, 183-205. http://dx.doi.org/10.1146/annurev.arplant.043008.092007

[18] Lichtenthaler, H.K. and Buschmann, C. (2001) Chlorophylls and Carotenoids: Measurement and Characterization by UV-VIS Spectroscopy. In: Wrolstad, R.E., Acree, T.E., An, H., Decker, E.A., Penner, M.H., Reid, D.S., Schwartz, S.J., Shoemaker, C.F. and Sporns, P., Eds., Current Protocols in Food Analytical Chemistry (CPFA), John Wiley and Sons, New York, F4.3.1-F4.3.8.

[19] Homme, P.M., Gonzalez, B. and Billard, J. (1992) Carbohydrate Content, Frutane and Sucrose Enzyme Activities in Roots, Stubble and Leaves of Rye Grass (Lolium perenne L.) as Affected by Source/Link Modification after Cutting. Journal of Plant Physiology, 140, 282-291. http://dx.doi.org/10.1016/S0176-1617(11)81080-1

[20] Yemm, E.W. and Willis, A.J. (1954) The Respiration of Barley Plants. IX. The Metabolism of Roots during the Assimilation of Nitrogen. New Phytologist, 55, 229-234. http://dx.doi.org/10.1111/j.1469-8137.1956.tb05283.x

[21] Herbert, D., Phipps, P.J. and Strange, R.E. (1971) Chemical Analysis of Microbial Cells. Methods in Microbiology, 5B, 209-344. http://dx.doi.org/10.1016/S0580-9517(08)70641-X

[22] Smith, F., Gilles, M.A., Hamilton, J.K. and Godees, P.A. (1956) Colorimetric Method for Determination of Sugar Related Substances. Analytical Chemistry, 28, 350. http://dx.doi.org/10.1021/ac60111a017

[23] Bates, L.S., Waldan, R.P. and Teare, L.D. (1973) Rapid Determination of Free Proline under Water Stress Studies. Plant and Soil, 39, 205-207. http://dx.doi.org/10.1007/BF00018060

[24] Vartanain, N., Hervochon, P. Marcolte, L. and Larher, F. (1992) Proline Accumulation during Drought Rhizogenesis in Brassica napus var. oleifera. Journal of Plant Physiology, 140, 623-628. http://dx.doi.org/10.1016/S0176-1617(11)80799-6

[25] Yemm, E.W. and Cocking, E.C. (1955) The Determination of Amino Acids with Ninhydrin. Analyst, 80, 209-213. http://dx.doi.org/10.1039/an9558000209

[26] Bradford, M.M. (1976) A rapid and Sensitive Method for Quantitation of Microgram Quantities of Protein Utilizing the Principle of Protein-Dye-Binding. Analytical Biochemistry, 72, 248-254. 
http://dx.doi.org/10.1016/0003-2697(76)90527-3

[27] Wasfy, W.S. and Orrin, E.S. (1975) Identification of Plant Hormones from Cotton Ovules. Plant Physiology, 55, 550554.

[28] Shindy, W.W. and Smith, O. (1975) Identification of Plant Hormones from Cotton Ovules. Plant Physiology, 55, 550-554. http://dx.doi.org/10.1104/pp.55.3.550

[29] Chen, J.X. and Wang, X.F. (2006) Plant Physiology Experimental Guide. Higher Education Press, Beijing, 24-25, 5556.

[30] Kumar, K.B. and Khan, P.A. (1982) Peroxidase and Polyphenol Oxidase in Excised Ragi (Eleusine coracana cv. PR 202) Leaves during Senescence. Indian Journal of Experimental Botany, 20, 412-416.

[31] Giannopolitis, C.N. and Ries, S.K. (1977) Purification and Quantitative Relationship with Water-Soluble Protein in Seedlings. Plant Physiology, 59, 315-318.

[32] Chapman, H.O. and Pratt, P.E. (1978) Methods of Analysis for Soils, Plants and Water. Division of Agriculture Sciences University California, Berkley, 5-6.

[33] Snedecor, G.M. and Cochran, W.C. (1969) Statistical Methods. 6th Edition, Iowa University Press. Ames, Iowa.

[34] Creelman, R.A. and Mullet, J.E. (1997) Oligosaccharins, Brassinolides, and Jasmonates: Nontraditional Regulators of Plant Growth, Development, and Gene Expression. The Plant Cell, 9, 1211-1223. http://dx.doi.org/10.1105/tpc.9.7.1211

[35] Kusaka, M., Lalusin, A.G. and Fujimura, T. (2005) The Maintenance of Growth and Turgor in Pearl Millet (Pennisetum glaucum (L.) Leeke) Cultivars with Different Root Structures and Osmo-Regulation under Drought Stress. Plant Science, 168, 1-14. http://dx.doi.org/10.1016/j.plantsci.2004.06.021

[36] Ripley, B.S., Gilber, M.E., Ibrahim, D.G. and Osborne, C.P. (2007) Drought Constraints on C 4 Photosynthesis: Stomatal and Metabolic Limitations in $\mathrm{C}_{3}$ and $\mathrm{C}_{4}$ Subspecies of Alloteropsis semialata. Journal of Experimental Botany, 58, 1351-1363. http://dx.doi.org/10.1093/jxb/erl302

[37] Sheng, M., Tang, M., Chan, H., Yang, B., Zhang, F. and Huang, Y. (2008) Influence of Arbuscular Mycorrhizae on Photosynthesis and Water Status of Maize Plants under Salt Stress. Mycorrhiza, 18, 287-296. http://dx.doi.org/10.1007/s00572-008-0180-7

[38] Mittler, R. (2002) Oxidative Stress, Antioxidants, and Stress Tolerance. Trends in Plant Science, 7, 405-410. http://dx.doi.org/10.1016/S1360-1385(02)02312-9

[39] Murkute, A.A., Sharma, S. and Singh, S.K. (2006) Studies on Salt Stress Tolerance of Citrus Rootstock Genotypes with Arbuscular Mycorrhizal Fungi. Horticultural Science, 33, 70-76.

[40] EL-Bassiouny, H.M.S. (1997) Studies on the Role of Abscisic as Antitranspirant on Growth, Chemical Analysis and Yield Components of Cowpea Plants in Presence of Soil Conditioners Egypt. The Journal of Physiological Sciences, $\mathbf{3}$, 409-432.

[41] Fischer, C. and Holl, W. (1991) Food Reserves in Scots Pine (Pinus sylvestris L.). I. Seasonal Changes in the Carbohydrate and Fat Reserves of Pine Needles. Trees, 5, 187-195. http://dx.doi.org/10.1007/BF00227524

[42] Patakas, A. and Noitsakis, B. (2001) Leaf Age Effects on Solute Accumulation in Water-Stressed Grapevines. Plant Physiology, 158, 63-69. http://dx.doi.org/10.1078/0176-1617-00003

[43] Hoekstra, F.A. and Buitink, J. (2001) Mechanisms of Plant Desiccation Tolerance. Trends in Plant Science, 8, 431-438. http://dx.doi.org/10.1016/S1360-1385(01)02052-0

[44] Khattab, H. (2007) Role of Glutathione and Polyadenylic Acid on the Oxidative Defense Systems of Two Different Cultivars of Canola Seedlings Grown under Saline Conditions. Australian Journal of Basic and Applied Sciences, 1, 323-334.

[45] Sadak, M.Sh., Abdelhamid, T.M. and El-Saady, A.M. (2010) Physiological Responses of Faba Bean Plant to Ascorbic Acid Grown under Salinity Stress. Egyptian Journal of Agronomy, under press.

[46] Gzik, A. (1996) Accumulation of Proline and Pattern of $\alpha$-Amino Acids in Sugar Beet Plants in Response to Osmotic, Water and Salt Stress. Environmental and Experimental Botany, 36, 29-38. http://dx.doi.org/10.1016/0098-8472(95)00046-1

[47] Bandurska, H. (1993) In Vivo and in Vitro Effect of Proline on Nitrate Reductase Activity under Osmotic Stress in Barley. Acta Physiologiae Plantarum, 15, 83-88.

[48] Rajaravindran, M. and Natarajan, S. (2012) Effects of Salinity Stress on Growth and Biochemical Constituents of the Halophyte Sesuvium portulacastrum. International Journal of Research in Biological Sciences, 2, 18-25.

[49] Krasensky, J. and Jonak, C. (2013) Drought, Salt, and Temperature Stress-Induced Metabolic Rearrangements and Regulatory Networks. Journal of Experimental Botany, 4, 1593-1608. 
[50] Harinasut, P., Srisunak, S., Pitukchaisopol, S. and Charoensataporn, R. (2000) Mechanisms of Adaptations to Increasing Salinity of Mulberry: Proline Content and Ascorbate Peroxidase Activity in Leaves of Multiple Shoots. ScienceAsia, 26, 207-211. http://dx.doi.org/10.2306/scienceasia1513-1874.2000.26.207

[51] Hoque, M.A., Okuma, E., Banu, M.N.A., Nakamura, Y., Shimoishi, Y. and Murata, Y. (2007) Exogenous Proline Mitigates the Detrimental Effects of Salt Stress More than Exogenous Betaine by Increasing Antioxidant Enzyme Activities. Journal of Plant Physiology, 164, 553-561.

[52] Rohwer, C.L. and Erwin J.E. (2008) Horticultural Applications of Jasmonates: A Review. The Journal of Horticultural Science and Biotechnology, 83, 283-304.

[53] Mahmood, M., Bidabadi, S.S., Ghobadi, C. and Gray, D.J. (2012) Effect of Methyl Jasmonate Treatments on Alleviation of Polyethylene Glycol-Mediated Water Stress in Banana (Musa acuminata cv. "Berangan”, AAA) Shoot Tip Cultures. Plant Growth Regulation, 68, 161-169. http://dx.doi.org/10.1007/s10725-012-9702-6

[54] Shakirova, F.M., Sakhabutdinova, A.R., Bezrukova, M.V., Falkhutdinova, R.A. and Fatkhutdinova, D.R. (2003) Changes in the Hormonal Status of Wheat Seedlings Induced by Salicylic Acid and Salinity. Plant Science, 164, 317-322. http://dx.doi.org/10.1016/S0168-9452(02)00415-6

[55] Sakhabutdinova, A.R., Fatkhutdinova, D.R., Bezrukova, M.V. and Shakirova, F.M. (2004) Salicylic Acid Prevents the Damaging Action of Stress Factors on Wheat Plant Bulg. Bulgarian Journal of Plant Physiology, Special Issue 2003, 314-319.

[56] Setter, T.L., Yan, J., Warburton, M., Ribaut, J.M., Xu, Y., Sawkins, M., Buckler, E.S., Zhang, Z. and Gore, M.A. (2011) Genetic Association Mapping Identifies Single Nucleotide Polymorphisms in Genes That Affect Abscisic Acid Levels in Maize Floral Tissues during Drought. Journal of Experimental Botany, 62, 701-716. http://dx.doi.org/10.1093/jxb/erq308

[57] Gonzalez, E.M., Galvez, L. and Arrese-Igor, C. (2001) Abscisic Acid Induces a Decline in Nitrogen Fixation That Involves Leghemoglobin, but Is Independent of Sucrose Synthase Activity. Journal of Experimental Botany, 52, 285-293. http://dx.doi.org/10.1093/jexbot/52.355.285

[58] Majid, N.A. and Akbar, N. (2006) A Possible Role for Methyl Jasmonate in Affecting Superoxide Dismutase and Catalase Activities under PQ-Induced Oxidative Stress in Maize Seedlings. Journal of Biological Sciences, 6, 55-60. http://dx.doi.org/10.3923/jbs.2006.55.60

[59] Norastehnia, A. and Nojavan-Asghari, M. (2006) Effect of Methyl Jasmonate on the Enzymatic Antioxidant Defense System in Maize Seedling Subjected to Paraquat. Asian Journal of Plant Sciences, 5, 17-23. http://dx.doi.org/10.3923/ajps.2006.17.23

[60] Keramat, B., Kalantari, K.M. and Arvin, M.J. (2009) Effects of Methyl Jasmonate in Regulating Cadmium Induced Oxidative stress in Soybean Plant (Glycine max L.). African Journal of Biotechnology, 3, 240-244.

[61] Choudhury, S. and Panda, S.K. (2004) Role of Salicylic Acid in Regulating Cadmium Induced Oxidative Stress in Oryza sativa L. Roots. Bulgarian Journal of Plant Physiology, 30, 95-110.

[62] Li, L., Staden, J.V. and Jager, A.K. (1998) Effect of Plant Growth Regulators on the Antioxidant System in Seedlings of Two Maize Cultivars Subjected to Water Stress. Journal of Plant Growth Regulation, 25, 81-87. http://dx.doi.org/10.1023/A:1010774725695

[63] Jung, S. (2004) Effect of Chlorophyll Reduction in Arabidopsis thaliana by Methyl Jasmonate or Norflurazon on Antioxidant Systems. Plant Physiology and Biochemistry, 42, 231-255. http://dx.doi.org/10.1016/j.plaphy.2004.01.001

[64] Tariq, A., Masroor, M., Khan, A., Mohd, I., Naeem, M., Moinuddin, I. and Nadeem, H. (2011) Methyl Jasmonate Counteracts Boron Toxicity by Preventing Oxidative Stress and Regulating Antioxidant Enzyme Activities and Artemisinin Biosynthesis in Artemisia annua L. Protoplasma, 248, 601-612.

[65] Ruiz-Lozano, J.M., Azcón, R. and Gómez, M. (1995) Effects of Arbuscular-Mycorrhizal Glomus Species on Drought Tolerance: Physiological and Nutritional Plant Responses. Applied and Environmental Microbiology, 61, 456-460.

[66] Morte, A., Lovisolo, C. and Schubert, A. (2000) Effect of Drought Stress on Growth and Water Relations of the Mycorrhizal Association Helianthemum almeriense-Terfezia claveryi. Mycorrhiza, 10, 115-119. http://dx.doi.org/10.1007/s005720000066

[67] Baque, M.A., Karim, M.A., Hamid, A. and Tetsushi, H. (2006) Effect of Fertilizer Potassium on Growth, Yield and Nutrient Uptake of Wheat (Triticum aestivum L.) under Water Stress Conditions. South Pacific Studies, 27, 25-35.

[68] Maria, A.M., Gendy, A.A., Selim, A.H. and Abd El.-All, A.M. (2008) Response of Wheat Plants Grown under Water Stress in Relation to Jasmonic Acid. Minufiya Journal of Agricultural Research, 33, 1355-1375.

[69] Hammad, S.A.R. and Ali, O.A.M. (2014) Physiological and Biochemical Studies on Drought Tolerance of Wheat Plants by Application of Amino Acids and Yeast Extract. Annals of Agricultural Sciences, 59, 133-145.

http://dx.doi.org/10.1016/j.aoas.2014.06.018 
Scientific Research Publishing (SCIRP) is one of the largest Open Access journal publishers. It is currently publishing more than 200 open access, online, peer-reviewed journals covering a wide range of academic disciplines. SCIRP serves the worldwide academic communities and contributes to the progress and application of science with its publication.

Other selected journals from SCIRP are listed as below. Submit your manuscript to us via either submit@scirp.org or Online Submission Portal.
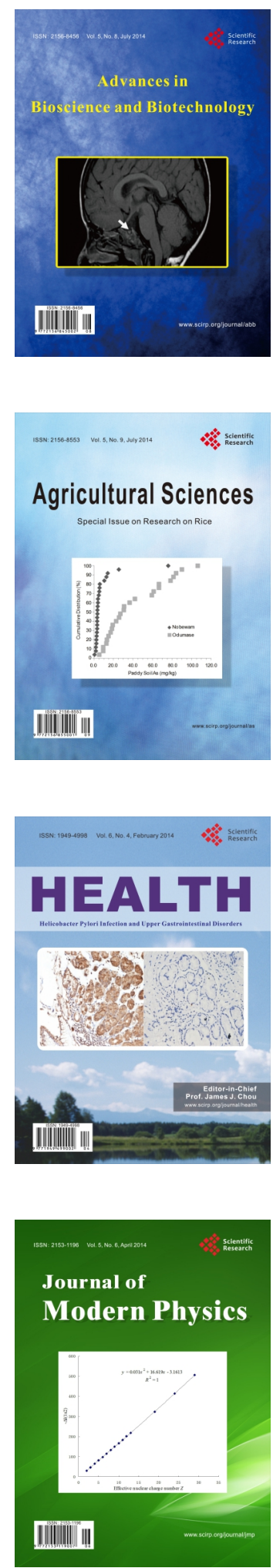
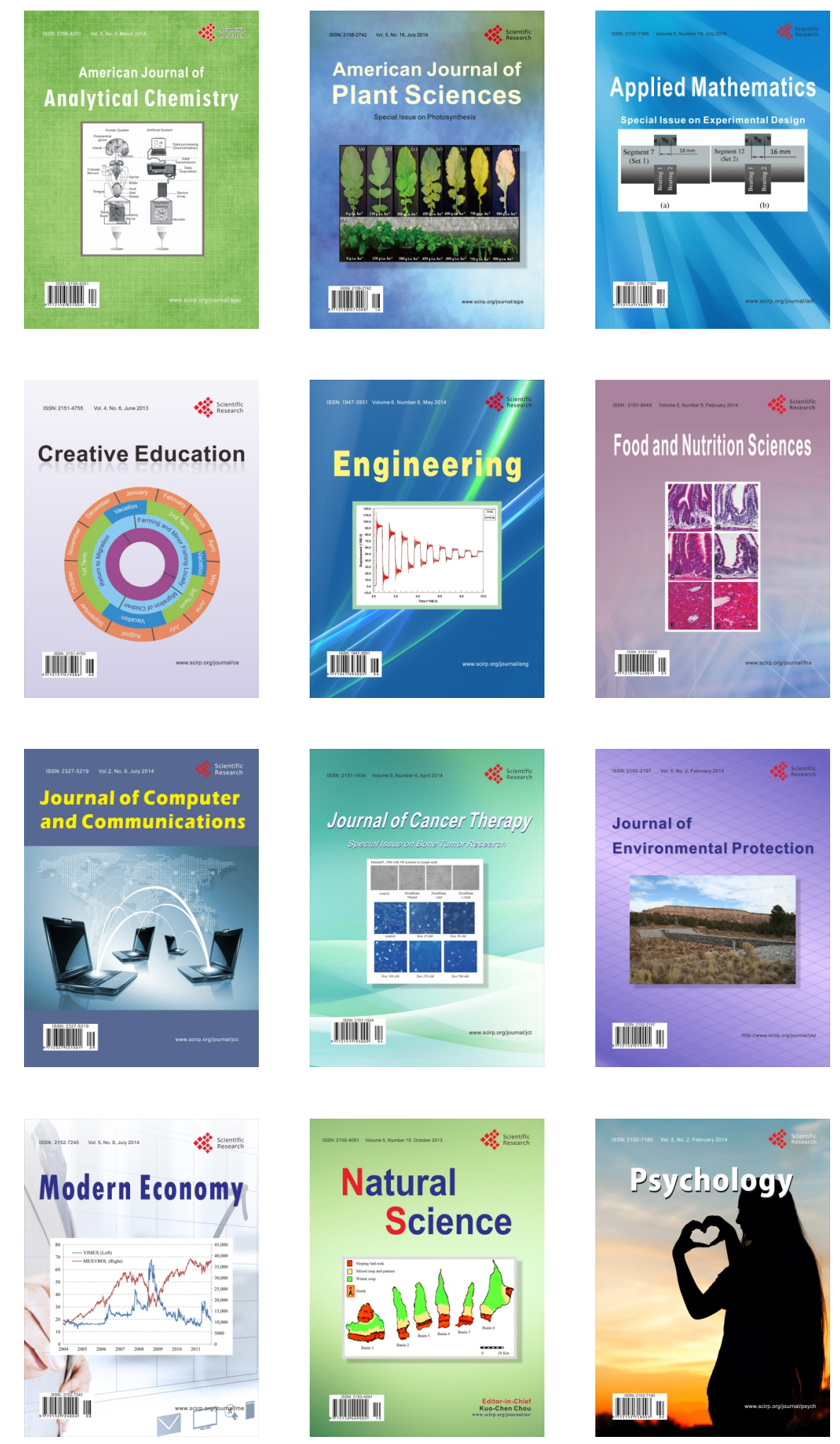